\title{
A clinical review of depression in elderly people
}

\author{
A Amati \\ From de Senectute: Age and Health Forum \\ Catanzaro, Italy. 5-7 December 2009
}

\section{Background}

Almost $20 \%$ of people over 65 show depressive symptoms while approximately $36 \%$ of demented over 75 -ear-olds are suffering from moderate-mild depression and about $40 \%$ of people over 85 are affected by a depressive condition [1] Having a negative self-perception and fearing social stigma because of that, stops older people asking for any psychiatric help. Moreover, their somatic complaints are attracting much more interest due to several illnesses being in comorbity with depression. So, almost half of geriatric depression remains undiagnosed, although they are a condition with a high risk of suicide. People over 65 committed $19 \%$ of all suicides in USA: $93 \%$ of them had a depressive disorder in comorbility with a painful medical disease.

\section{Clinical evidence}

Elderly people may suffer from all types of depressive disorders: however, their clinical pictures are different from adults, [2] showing predominant anxiety, insomnia, cognitive impairment, anhedonia, and agitation and less evident symptoms in the affective- mood domain.

Enhanced personality traits, modified behavioural patterns and interpersonal capacities are effects of the aged brain, when subjects are confronted with personal adjustments to life changes.

Multifactorial risk for depression involves the bio-psycho-social context: family history of depression, use of several drugs ( BDZ, NSAF) or abuse of common substances (alcohol), somatic diseases with disability and/or chronic pain, permanent damage to body image, daily loneliness and social isolation, recent grief's, reduce perception of self wellness, fear of death, as well as availability of social support and economic resources, capacity of living in the community or need for assisted residency .

\footnotetext{
Dpt.of Experimental and Clinical Medicine, Magna Græcia University , Catanzaro, Italy
}

Depressive Disorders in aged population, according to their predominant clinical features, may pertain to the following groups,:

- Biological: early onset, Bipolar spectrum, Melancolia, Psychotic or Atypical Depression

- Psycho-reactive: late onset, relevant loss events or persistent stressful conditions such as isolation or disability or a severe medical condition

- Mixed, organic + psychological: post-stroke depression, CNS altering neurotransmission drugs or metabolic adverse effects of poly- medication; initial Dementia or Parkinson Disease;

- Depressive pseudodementia, temporary and reversible symptoms within the same neuropsychological domains of AD [3-5]

\section{Conclusions}

Relapse of an earlier depression is possible in later life but usually depression occurring for the first time may depend on another medical illness. Somatic complaints without any apparent medical etiology can be found. Clinical diagnosis of depression versus dementia can be really difficult, although some key features may help to detect depressive disorders [6] Cognitive assessment, corroborated by neuroimaging investigation, is required, in order to establish appropriate treatment.

Published: 19 May 2010

References

1. Stekml ML, Vinkers DJ, Roos JR, Van der Mast ATF, Beekman RGJ: Natural History of Depression in oldest old. Population-Based prospective Study Brit J Psychiatry 2006, 188:65-69.

2. Gallo JJ, Rabins PV: Depression Without Sadness, Alternative Presentation of Depression in Late Life. Am Fam Physician. 1999, 60(3):820-826.

3. Bulbena A, Berrios GE: Pseudodementia, facts and figures Brit J Psychiatry. 1986, 148:87-94.

4. Alexoupulos GS, Young RC, Mayers BS: Geriatric Depression: age of onset and Dementia. Biol Psychiatry 1993, 34:141-145. 
5. Yousef G, Ryan WJ, Lambert T, Pitt B, Kellett J: A preliminary report : a new scale to identify the pseudodementia syndrome. Int I Geriat Psychiatry 1998, 13:389-399.

6. Halperin I, Korczyn AD: Late-life depression as a risk factor for dementia. Future Neurology 2007, 2:201-208.

doi:10.1186/1471-2318-10-S1-L28

Cite this article as: Amati: A clinical review of depression in elderly people. BMC Geriatrics 2010 10(Suppl 1):L28.

Submit your next manuscript to BioMed Central and take full advantage of:

- Convenient online submission

- Thorough peer review

- No space constraints or color figure charges

- Immediate publication on acceptance

- Inclusion in PubMed, CAS, Scopus and Google Scholar

- Research which is freely available for redistribution

Submit your manuscript at www.biomedcentral.com/submit
C Biomed Central 